\title{
PERAN PERSEPSI DUKUNGAN ATASAN TERHADAP KINERJA INDIVIDUAL KARYAWAN DENGAN SELF-EFFICACY SEBAGAI MEDIATOR
}

\author{
Mutia Kusuma Dewi ${ }^{1}$ dan Rostiana ${ }^{2}$ \\ ${ }^{1}$ Fakultas Psikologi, Universitas Tarumanagara \\ Email: mutiakusumadewi@gmail.com \\ ${ }^{2}$ Fakultas Psikologi, Universitas Tarumanagara \\ Email: rostiana@fpsi.untar.ac.id
}

\begin{abstract}
ABSTRAK
Sumber utama untuk mendukung daya saing dan kinerja organisasi ditentukan oleh kinerja individual yang tinggi. Dengan tingginya kinerja individual, maka dapat dipastikan kinerja tim dan organisasi juga meningkat, dengan demikian produktivitas dan kemampuan bersaing perusahaan pun meningkat, dan secara tidak langsung dapat meningkatkan pergerakan pada sektor ekonomi kearah yang positif. Oleh karena itu, tujuan utama dalam penelitian ini adalah untuk dapat menelaah lebih dalam keterkaitan variabel kinerja individual karyawan dengan persepsi dukungan atasan dalam sebuah model mediasi dimana self-efficacy sebagai mediator. Data dikumpulkan dari 130 karyawan millennials di sebuah perusahaan Konsultan di Jakarta. Pengambilan data dilakukan dengan menyebarkan kuesioner Individual Work Performance Questionnaire (IWPQ), Supervisor Support Scale, Occupational SelfEfficacy. Pengolahan data dengan menggunakan regresi linier telah membuktikan bahwa hubungan persepsi dukungan atasan memiliki tingkat keterkaitan yang rendah dan signifikan dengan kinerja individual karyawan. Namun dalam analisis mediasional, self-efficacy mampu meningkatkan keterkaitan antara kedua variabel tersebut, sehingga disimpulkan bahwa self-efficacy merupakan mediator penuh (full mediator). Dengan demikian, secara keseluruhan temuan ini dengan jelas membuktikan bahwa persepsi dukungan atasan karyawan mampu meningkatkan kinerja individual karyawan millenials dengan adanya mediasi dari self-efficacy.
\end{abstract}

Kata Kunci: kinerja individual karyawan, persepsi dukungan atasan, self-efficacy

\section{PENDAhuluan}

Pada tahun 2017, berdasarkan laporan The Global Competitiveness Index 2017-2018 yang dirilis oleh World Economic Forum (WEF), daya saing Indonesia secara global tahun ini berada pada posisi ke-36 dari 137 negara di dunia. Peringkat tersebut naik 5 poin dari posisi tahun lalu. Meskipun naik 5 peringkat, peringkat daya saing Indonesia masih berada di bawah negara Thailand di posisi 32, Malaysia di posisi 23, dan Singapura di posisi 3. Berdasarkan fakta-fakta tersebut, sebagai salah satu Lembaga penelitian terkemuka di Indonesia, LIPI, memberikan gambaran bahwa untuk meningkatkan daya saingnya, Indonesia harus dapat mendukung optimalisasi pengembangan Sumber Daya Manusia (SDM), IPTEK, dan inovasi sebagai pilar penting Indonesia (LIPI, 2017).

Sejalan dengan analisis The Global Competitiveness Index 2017 - 2018 oleh WEF, dikemukakan bahwa terdapat beberapa indikator dasar yang dapat menjadi faktor kunci pendorong ekonomi indonesia, diantaranya adalah faktor peran lembaga atau organisasi, pendidikan dan pelatihan SDM, serta perkembangan kondisi bisnis Indonesia. Diketahui bahwa sinergi peran pemerintah, swasta, dunia usaha atau industri menjadi upaya penting yang harus dilakukan untuk menguatkan daya saing Indonesia, khususnya dalam pengelolaan sumber daya manusia (SDM). Pengelolaan SDM secara tepat akan mendapatkan SDM yang bertumbuh-kembang dan berkualitas, berkinerja tinggi dalam mencapai tujuan dan sasaran bersama dalam sebuah organisasi (Noe, Hollenbeck, Gerhart, \& Wright, 2010). 
Koopmans, Bernaards, Hildebrandt, van der beek, dan de Vet (2014), menjelaskan bahwa salah satu cara pengelolaan SDM dalam organisasi yang relevan saat ini adalah dengan melakukan pengelolaan kinerja individual karyawan. Adanya peningkatan pesat dalam pergerakan barang, jasa, teknologi, dan kapital yang memunculkan persaingan antar perusahaan di seluruh dunia, merupakan tugas penting bagi organisasi atau perusahaan untuk mempertahankan atau meningkatkan kemampuan bersaing karyawan mereka. Kinerja individual karyawan (individual work perfomance) merupakan salah satu indikator kunci dalam kinerja tim dan perusahaan, sehingga berkontribusi terhadap produktivitas dan kemampuan bersaing perusahaan.

PT X, sebuah organisasi yang bergerak dalam bidang konsultansi manajemen SDM, yang berdiri sejak tahun 1967, merupakan organisasi pendidikan dan pengembangan manajemen pertama di Indonesia, diharapkan PT X mampu mengelola kinerja individualnya secara tepat untuk dapat meningkatkan daya saing usahanya. Namun, berdasarkan hasil tinjauan pengukuran kinerja karyawannya pengelolaan tersebut belum dijalankan secara tepat. Disampaikan bahwa hasil pengukuran kinerja yang direncanakan untuk digunakan dalam melakukan perencanaan aktivitas pengembangan karyawan, evaluasi kenaikan gaji (remunerasi), dan golongan karir karyawan belum berjalan sesuai rencana. Fenomena yang terjadi saat ini adalah karyawan mengalami karir yang menetap (career plateau), mengalami hambatan dalam pelaksanaan pengembangan karyawan, dan adanya penurunan kinerja karyawan. Fenomena tersebut diduga karena kuranganya dukungan dari para atasan kepada karyawan PT X. Seperti diketahui, peran atasan menjadi salah satu faktor yang sangat menentukan, karena atasan memiliki peran dalam melaksanakan evaluasi kinerja, pengaturan kerja, peningkatan kompetensi, dan kompensasi bawahan di PT X.

Hal yang kurang menguntungkan bagi PT X adalah munculnya fenomena pergeseran demografi usia karyawan yang ditandai dengan adanya peningkatan angka tenaga kerja dengan usia pensiun (diatas 50 tahun) dan meningkatnya jumlah karyawan dengan usia produktif ( 18 - 37 tahun) (Howe \& Strauss, 2000; dalam Reeves \& Oh, 2008). Badan Koordinasi Keluarga Berencana Nasional (BKKBN) memprediksi bahwa pada 2020-2030 mendatang, dengan adanya pergeseran demografis usia karyawan, Indonesia akan didominasi oleh tenaga kerja pada rentang usia 15 hingga 64 tahun yang mencapai 180 juta jiwa (70\%). Kesimpulan tersebut didapatkan dari hasil cerminan perhitungan populasi penduduk Indonesia berusia antara 15 tahun hingga 34 tahun yang telah mencapai 34,45\% saat ini (Media Indonesia Online, 2017).

Dengan adanya dominasi jumah karyawan millennials di PT X, maka menjadi hal yang penting bagi PT X untuk mulai memprioritaskan generasi millennials. Dengan adanya fenomena penurunan kinerja karyawan dan kurangnya dukungan atasan diduga akan menjadi ancaman masa depan PT X, dapat diprediksi karyawan millennials akan mengalami penurunan kinerja dan loyalitas, yang pada akhirnya akan mengakibatkan penurunan kinerja dan produktivitas organisasi (Ng, Schweitzer, \& Lyons, 2010; Myers \& Sadaghiani, 2010).

Mengacu pada fenomena-fenomena tersebut, maka terdapat 2 variabel penting yang menjadi fokus utama dalam penelitian ini, yaitu variabel kinerja individual dan persepsi dukungan atasan. Beberapa penelitian yang telah dilakukan oleh para ahli mengenai variabel dukungan atasan dan kinerja, terungkap bahwa nyatanya peranan dukungan atasan terhadap kinerja karyawan masih cenderung rendah dan bahkan tidak secara signifikan berperan langsung (direct) terhadap kinerja karyawan. Penelitian yang dilakukan oleh Azman, Ajis, Dollah, dan Boerhannoeddin (2009); Shanock dan Eisenberger (2006), yang menunjukkan bahwa dukungan atasan tidak memiliki pengaruh kuat terhadap peningkatkan kinerja karyawan. Bahkan, dalam penelitiannya lainnya, Ballatine \& Nunns (1998) menyatakan bahwa dukungan atasan tidak memiliki pengaruh langsung 
(indirect relationship) terhadap kinerja karyawan. Oleh karena itu, untuk dapat menjelaskan penemuan tersebut, konsep Schermerhorn, Hunt, dan Osborn (1982; dalam Rahadi, 2010), menerangkan bahwa dukungan atasan sebagai komponen lingkungan ternyata bukan satu-satunya komponen penting yang berperan dalam peningkatan kinerja karyawan, masih terdapat komponen penting lain yang cukup berperan dalam peningkatan kinerja karyawan, yaitu komponen personal (individual attributs). Salah satu komponen personal yang menjadi bagian dalam variabel penelitian ini adalah self-efficacy.

Beberapa penelitian yang melibatkan variabel self-efficacy dan kinerja karyawan membuktikan bahwa self-efficacy memiliki peran yang kuat terhadap kinerja. Seperti penelitian yang dilakukan oleh Walumbwa, Avolio, dan Zhu, (2008) yang mengungkapkan hubungan yang kuat antara selfefficacy dengan kinerja individual karyawan $(\beta=0.21, p<0.01)$. Ballatine dan Nunns $(1998)$ turut menjelaskan bahwa self-efficacy dengan kinerja memiliki hubungan yang kuat. Hal ini ditunjukkan dengan penelitian yang mereka lakukan dengan menggunakan analisis regresi antara self-efficacy dan penilaian kinerja atasan yang menghasilkan nilai $\mathrm{R}^{2}$ sebesar $0.72(\mathrm{p}<0.01)$. Dalam penelitian meta-analysis yang dilakukan Cherian dan Jacob (2013), mereka melakukan review terhadap literatur mulai dari tahun 2000 - 2012 yang melibatkan variabel self-efficacy dan kinerja. Dari penelitian tersebut dibuktikan bahwa self-efficacy merupakan variabel yang memiliki keterkaitan yang kuat dengan kinerja.

Dalam Byrne, Dik, dan Chiaburu (2008) disampaikan bahwa self-efficacy memfasilitasi peningkatan kinerja dalam domain tertentu. Secara teori, ketika karyawan yang berkemampuan rendah mendapatkan penghargaan setelah menyelesaikan tugas, self-efficacy diyakini dapat meningkatan perilaku kerja relevan individu terhadap tugasnya (task-relevant behavior), karena keyakinan self-efficacy diperoleh atas pencapaian kinerja dapat mempengaruhi kondisi afektif dan fisiologis individu tersebut (Lent, 2005; dalam Byrne, et al., 2008). Stajkovic dan Luthans (1998) memperkuat dengan menerangkan bahwa self-efficacy merupakan alat dalam menumbuhkan motivasi dan pembelajaran secara simultan. Oleh karena itu, individu yang memiliki self-efficacy yang tinggi akan dapat memilih situasi secara tepat dengan menyesuaikan pada kemampuan diri individu tersebut.

Dalam Kenny, Mohr, \& Levesque (2001) disampaikan bahwa varian yang dapat menjelaskan perilaku manusia lebih besar berkaitan dengan faktor personal dibandingkan dengan faktor situasi (lingkungan). Oleh karena itu, dalam penelitian ini self-efficacy diharapkan dapat memberikan kontribusi secara tidak langsung (indirect effect) terhadap peranan persepsi dukungan atasan dan kinerja individual karyawan. Dengan adanya self-efficacy dengan penempatan sebagai variabel mediator diharapkan dapat memberikan pengembangan yang baru dalam menjelaskan hubungan persepsi dukungan atasan dengan kinerja individual karyawan. Maka dari itu, peneliti membuat penelitian dengan hipotesis: Persepsi dukungan atasan berperan terhadap kinerja individual karyawan dengan self-efficacy sebagai mediator".

\section{METODE PENELITIAN}

Pada penelitian ini subjek melakukan pengambilan sampel dengan teknik purposive sampling, karena diambil adalah populasi karyawan dewasa muda (rentang usia 18 - 37 tahun) di PT X. Sampel responden yang akan diambil peneliti, yaitu 130 orang karyawan (dari jumlah populasi karyawan PT X sebanyak 278 orang), terdiri dari 43 orang (33.1\%) laki-laki dan 87 orang (66.9\%) perempuan, dengan dominasi rentang usia 28 - 32 tahun dengan persentasi sebesar $44 \%$, usia 23 - 27 tahun sebanyak 35\%, usia 33-37 tahun sebanyak 18\%, dan usia $18-22$ tahun sebanyak $2 \%$. 
Selain itu, subjek dengan Pendidikan setingkat S-1 mendominasi responden dalam penelitian ini, yaitu sebanyak 44,6\%, Pendidikan setingkat S-2 40,8\%, dan Pendidikan setingkat D-3 10,8\%, dan selanjutnya responden dengan Pendidikan setingkat SLTA adalah sebanyak 3,8\%. Peneliti menggunakan tiga variabel, yaitu kinerja individual, persepsi dukungan atasan, dan self-efficacy, dengan metode penelitian kuantitatif dan non-experimental.

Pengukuran kinerja individual, peneliti menggunakan alat ukur individual work performance questionnaire (IWPQ) milik Koopmans, et al. (2011), yang terdiri atas 47 butir pernyataan dengan dengan skala Likert 1 sampai dengan 5. Alat ukur ini mengukur 4 (empat) dimensi Kinerja Individual, yaitu: (a) task performance, (b) contextual performance, (c) adaptive performance, an (d) counter-work productive behaviour (CWB). Semakin tinggi skor pada variabel ini berarti partisipan semakin dapat menjalankan tugasnya dan mencapai tujuan perusahaan. Contoh butir dari IWPQ antara lain, "Saya bekerja untuk memenuhi target yang ditetapkan oleh perusahaan" (task performance; dengan 13 butir item); "Saya dapat memenuhi tanggung jawab yang dibebankan kepada saya dalam bekerja" (contextual performance; dengan 16 butir item); "Saya dapat memenuhi tanggung jawab yang dibebankan kepada saya dalam bekerja" (adaptive performance; dengan 8 butir item); "Saya berfokus pada hal negatif dari kondisi kerja, dan bukan pada hal yang positif" (counter work productive behaviour; dengan 10 butir item).

Peneliti melakukan uji reliabilitas terhadap skala kinerja individual tersebut dengan menggunakan nilai alpha cronbach dan mendapatkan koefisien sebesar 0,92. Dari hasil pengolahan data, terdapat butir yang tidak reliabel, maka peneliti menggugurkan satu per satu butir tersebut. Butir yang tidak reliabel merupakan butir yang memiliki nilai corrected item-total correlation berada di bawah nilai 0.2 atau bertanda negatif yang dapat meningkatkan nilai nilai internal konsistensi cronbach's alpha, sehingga peneliti harus menggugurkan item dalam skala ini.

Selanjutnya, untuk variabel persepsi dukungan atasan, peneliti menggunakan alat ukur supervisory support scale yang dikembangkan oleh Greenhaus et al. (1990). Alat ukur ini memiliki 9 daftar pernyataan, dengan skala likert 1 sampai dengan 5. Salah satu contoh butir pernyataan dalam pada alat ukur supervisory support scale adalah "Atasan saya peduli apakah saya mencapai tujuan karir saya atau tidak". Semakin tinggi skor persepsi karyawan terhadap dukungan atasan mereka, berarti semakin baik karyawan mempersepsikan dukungan atasannya dalam bekerja. Berdasarkan hasil penelitan yang dilakukan oleh Greenhaus, et. al., 1990; Litzky dan Greenhaus, 2007; dan Byrne et. al., 2008; persepsi dukungan atasan memiliki internal konsistensi dengan koefisien 0,92 sampai dengan 0,95. Sedangkan, berdasarkan uji reliabilitas yang dilakukan, nilai internal konsistensi supervisory support scale memiliki cronbach's alpha secara keseluruhan mencapai 0.92.

Variabel self-efficacy, peneliti menggunakan alat ukur self-efficacy yang dikembangkan oleh Rigotti, et al. (2008), yaitu occupational self-efficacy scale. Alat ukur ini memiliki 6 daftar pernyataan, dengan skala likert 1 sampai dengan 5. Salah satu contoh butir pernyataan dalam pada alat ukur ini adalah "ketika menghadapi masalah dengan pekerjaan, biasanya saya dapat menemukan beberapa alternatif solusi". Semakin tinggi skor self-efficacy, berarti semakin individu menilai dirinya mampu dalam melaksanakan tugas. Occupational self-efficacy scale ini diadaptasi oleh Riggoti, et al., (2008) dari skala general self-efficacy scale oleh Schwarzer dan Jerussalem (1995). Occupational self-efficacy scale memiliki internal konsistensi dengan koefisien 0.7 sampai dengan 0.9. Sedangkan berdasarkan uji reliabilitas yang dilakukan oleh peneliti, nilai internal konsistensi occupational self-efficacy scale memiliki cronbach's alpha secara keseluruhan mencapai 0.75 . 


\section{HASIL DAN PEMBAHASAN}

Dalam melakukan analisis terhadap ketiga variabel, peneliti melakukan pengujian hipotesis dengan menggunakan model mediator dalam melihat hubungan yang tidak langsung (indirect effect) pada persepsi dukungan atasan dan kinerja individual dengan self-efficacy sebagai mediator.

Analisis data pada penelitian ini dilakukan secara bertahap dengan menggunakan program SPSS 23, untuk melakukan uji regresi linear. Prosedur analisis mediasi dilakukan dengan melakukan pengolahan data menggunakan metode Bootstrap (Selig dan Preacer, 2008). Metode Bootstrap ini memiliki keunggulan dari metode Sobel Test untuk pengujian hipotesis, karena metode Bootstrap ini melakukan pengujian variabel mediator dalam multi-level model yang sangat baik untuk penelitian dengan sampel kecil dan/ atau jika data penelitian tidak berdistribusi secara normal (Preacher \& Hayes, 2012).

Dalam pengujian hipotesis, terdapat beberapa langkah yang harus dipenuhi. Baron dan Kenny (1986) menjelaskan bahwa terdapat 4 (empat) kondisi, yaitu pertama, koefisien path c pada model regresi linear pada hubungan independent variable dan dependent variable harus memiliki keterkaitan yang signifikan. Kedua, koefisien path a pada model regresi linear antara hubungan independent variable dan mediator variable harus memiliki keterkaitan yang signifikan. Ketiga, pada kondisi regresi berganda (multiple) pada path c' antara independent variable, dependent variable, dan mediator variable juga signifikan atau hubungan mediator variable dan dependent variable juga signifikan setelah mengontrol independent variable. Keempat, peranan independent variable terhadap dependent variable menjadi berkurang setelah adanya mediator variable (path c'). Artinya, jika dalam penelitian ini dapat memenuhi empat kondisi tersebut di atas, maka model yang diajukan terbukti sebagai model mediator (path z). Berikut ini adalah hasil pengolahan data penelitian yang diolah dengan mengacu pada empat kondisi model mediator tersebut.

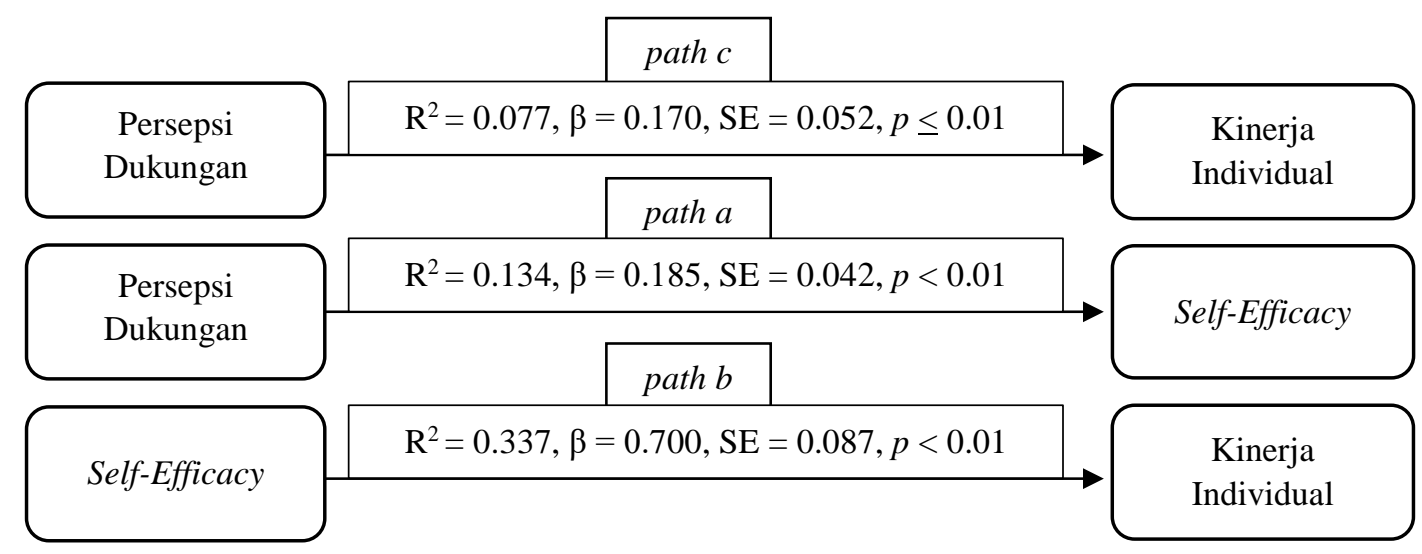

Gambar 1. Hasil uji regresi linear kinerja individual, persepsi dukungan atasan, dan self-efficacy 
Pertama, peneliti melakukan pengujian langsung (direct) antara variabel persepsi dukungan atasan dengan kinerja individual. Dengan menggunakan metode regresi linear diperoleh nilai $\mathrm{R}^{2}=0.077$; $\beta=0.170$ dengan tingkat signifikansi sebesar $p \leq 0.01$, artinya variabel persepsi dukungan atasan memiliki peranan sebesar $7,7 \%$ terhadap kinerja individual. Nilai $\beta=0.170$ menggambarkan tingkat kekuatan relasi langsung antara persepsi dukungan atasan dengan kinerja individual. Dengan demikian, variabel persepsi dukungan atasan memiliki tingkat kekuatan yang lemah terhadap kinerja individual.

Kedua, pengujian langsung (direct) dilakukan untuk melihat keterkaitan antara persepsi dukungan atasan dengan self-efficacy, diperoleh nilai $\mathrm{R}^{2}=0.134 ; \beta=0.185$ dengan tingkat signifikansi $p<$ 0.01 , artinya variabel persepsi dukungan atasan memiliki peranan sebesar 13,4\% terhadap selfefficacy. Nilai $\beta=0.185$ menggambarkan tingkat kekuatan relasi langsung antara persepsi dukungan atasan dengan self-efficacy. Dengan demikian disimpulkan bahwa variabel persepsi dukungan atasan memiliki keterikatan yang signifikan terhadap self-efficacy, namun dengan tingkat kekuatan yang masih cenderung lemah terhadap self-efficacy.

Ketiga, untuk melihat keterkaitan antara self-efficacy (mediator) dengan kinerja individual, peneliti melakukan pengujian secara tidak langsung (indirect) dengan menggunakan metode uji regresi berganda. Dari hasil uji regresi berganda pada gambar 4.2 (path c'), diperoleh nilai interaksi selfefficacy antara hubungan persepsi dukungan atasan dengan kinerja individual sebesar $\mathrm{R}^{2}=0.342$; $\beta=0.667$, dengan tingkat signifikansi $p<0.01$. Artinya, dengan pengujian regresi berganda, variabel self-efficacy memiliki keterkaitan positif dengan kinerja individual dengan tingkat kepercayaan yang cukup tinggi. Nilai $\beta=0.667$ menggambarkan tingkat keterikatan yang cukup tinggi antara self-efficacy dan kinerja individual (path z). Berdasarkan hasil tersebut, maka dapat dipastikan bahwa tingkat peranan persepsi dukungan atasan terhadap kinerja individual menjadi berkurang dan tidak signifikan setelah self-efficacy mengontrol dengan $\mathrm{R}^{2}=0.342, \beta=0.046$ dengan $p>0.05$. Artinya, 4 (empat) kondisi yang dikemukakan oleh Baron \& Kenny (1986) telah terpenuhi.

Selanjutnya, pengujian hipotesis dengan menggunakan hasil data regresi dilakukan dengan melakukan pembuktian model mediator dengan menggunakan metode Bootstrap (Preacher \& Hayes, 2012), dapat dilihat pada gambar berikut:

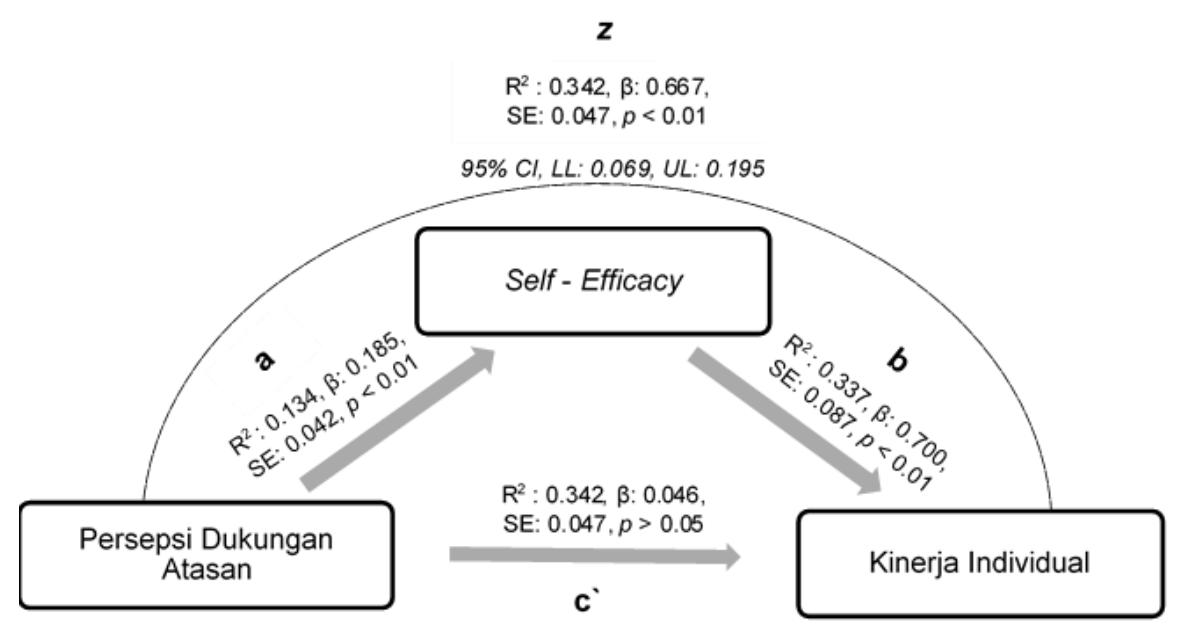

Gambar 2. Uji hipotesis keterikatan antara kinerja individual, persepsi dukungan atasan, dan selfefficacy sebagai mediator 
Berdasarkan data diatas, dilakukan pengujian hipotesis uji mengenai peranan persepsi dukungan atasan terhadap kinerja individual dengan self-efficacy sebagai mediator. Pada Gambar 4.2, berdasarkan model mediasi ( ath $c^{\prime}$ ), variabel persepsi dukungan atasan tidak signifikan memiliki keterkaitan dengan kinerja individual $\left(\mathrm{R}^{2}=0.342, \beta=0.046, p>0.05\right)$ ketika diikutsertakan variabel self-efficacy pada pengolahan uji regresi. Sebagai variabel mediator self-efficacy signifikan memiliki keterikatan positif dengan variabel kinerja individual $\left(\mathrm{R}^{2}=0.342, \beta=0.667, p\right.$ $<0.01$ ), artinya jika persepsi dukungan atasan tidak lagi mempunyai pengaruh terhadap kinerja individual, maka dapat diasumsikan bahwa terjadi efek mediasi. Hasil dari metode Bootstrap untuk membuktikan model mediator (indirect effect), dapat dipastikan self- efficacy dinyatakan sebagai mediator penuh (full mediator) antara hubungan variabel persepsi dukungan atasan dengan kinerja individual (95\% CI, lower level: 0.069, upper level: 0.195), artinya jika indirect effect dalam tingkat kepercayaan 95\% ( $\mathrm{p} \leq 0,05)$ dan pada salah satu level tidak mengandung nol atau negatif, maka dapat dikatakan bahwa adanya mediasi yang dilakukan oleh mediator variable (Preacher \& Hayes, 2004). Untuk melihat hasil pengujian mediator dengan metode Bootstrap dapat dilihat pada Gambar 2.

Dengan demikian, dapat disimpulkan bahwa persepsi dukungan atasan memiliki peranan terhadap kinerja karyawan di PT X dengan self-efficacy sebagai mediator. Dalam model mediasi ini, selfefficacy merupakan full mediator antara persepsi dukungan atasan dan kinerja individual. Sehingga, peran self-efficacy sebagai mediator dapat meningkatkatkan peran persepsi dukungan atasan terhadap kinerja individual.

Sebagai mediator self-efficacy memiliki peranan yang kuat dalam memediasi hubungan persepsi dukungan atasan dan kinerja karyawan. Dengan demikian, untuk dapat meningkatkan kinerja karyawan, khususnya karyawan pada generasi Y (millennials), diperlukan peranan aktif atasan untuk membentuk self-efficacy karyawan. Dengan karakteristik millennials yang selalu membutukan umpan balik dari atasan mereka untuk mencapai self-development, merupakan bagian terbaik yang dapat dimanfaatkan oleh PT X untuk melakukan pembentukan self-efficacy demi mencapai kinerja optimal mereka. Dengan adanya umpan balik kinerja, pemberian tugastugas yang menantang, dukungan atasan terhadap pembinaan karir, diharapkan karyawan juga dapat mengetahui kesempatan untuk mengembangkan keahlian mereka untuk bertumbuh bersama organisasi (Bacal, 2002; Greenhaus, et al., 1990). Dengan demikian, dalam diri karyawan akan terbentuk self-efficacy atau kepercayaan diri atas kemampuan mereka dan meyakini bahwa kemampuan mereka sangat dihargai dan dibutuhkan oleh organisasi.

\section{SIMPULAN \& SARAN}

Dalam penelitian ini telah terbukti bahwa self-efficacy berperan sebagai mediator, dan dapat memediasi secara penuh keterikatan antara persepsi dukungan atasan dengan kinerja individual karyawan. Maka, untuk dapat berperan sebagai mediator, para atasan harus dapat meningkatkan rasa kepercayaan karyawan terhadap kemampuan dan kompetensinya, sehingga karyawan akan memberikan kinerja terbaik mereka untuk perusahaan. Hasil temuan tersebut, sesuai dengan studi meta-analysis yang telah dilakukan oleh Chen, Casper dan Cortina (2001); Stajkovic \& Luthans (1998) menyampaikan bahwa self-efficacy secara empiris merupakan variabel yang memiliki hubungan yang kuat dengan variabel kinerja.

Untuk dapat mempertajam hasil temuan tersebut, Teori sosial - kognitif yang dikembangkan oleh Bandura (1971) menjelaskan bahwa self-efficacy memainkan peran penting dalam peningkatan kinerja atau kemampuan individu dalam mencapai tujuan atau menghasilkan sesuatu. individu 
membentuk kepercayaan terhadap seseorang berdasarkan perkataan dan dukungan yang diberikan, berupa nasihat (dorongan verbal), pemberian umpan balik, ataupun coaching. Informasi mengenai kemampuan yang disampaikan secara verbal oleh orang yang berpengaruh (atasan) akan meningkatkan self-efficacy seseorang dalam melakukan tugas atau menghasilkan kinerja yang tinggi. Bandura (1997) menyatakan bahwa tindakan-tindakan yang bersifat persuasif membuat individu berusaha dengan cukup keras untuk memperoleh kesuksesan. Individu tersebut juga akan berusaha untuk mengembangkan keahlian dan keyakinan dirinya.

Individu yang memiliki self-efficacy yang terbentuk berdasarkan persepsi mereka terhadap dukungan atasan akan membentuk suatu keyakinan atau kepercayaan individu untuk dapat menyelesaikan tugas ataupun mencapai target kerja, sehingga akan menghasilkan kinerja yang tinggi. Hal ini telah dibuktikan pada penelitian yang dilakukkan oleh Stajkovic \& Luthans (1998); Chen et. al., (2001); Bandura dan Locke (2003); Rigotti, et.al (2008); yang menyimpulkan bahwa self-efficacy merupakan determinan yang kuat terhadap kinerja karyawan.

Adanya isu globalisasi dan penuruan kinerja karyawan pada tahun 2017 ini, serta meningkatnya industri jasa konsutansi global yang mendominasi, PT X sebagai perusahaan lokal yang bergerak dalam industri jasa konsultansi SDM, penting untuk melakukan perbaikan dan pengembangan untuk meningkatkan daya saingnya di masa mendatang. Berdasarkan hasil temuan peneltian yang telah dilakukan, dapat disampaikan bahwa salah satu kunci dalam meningkatkan daya saingnya, PT X harus sedini mungkin memulai untuk memupuk self-efficacy karyawan untuk meningkatkan kinerja karyawan.

Untuk dapat meningkatkan kinerja karyawannya, khususnya karyawan pada generasi millennials, diperlukan peranan aktif atasan untuk membentuk self-efficacy karyawan. Dengan karakteristik millennials yang selalu membutukan umpan balik dari atasan mereka untuk mencapai selfdevelopment, merupakan bagian terbaik yang dapat dimanfaatkan oleh PT X untuk melakukan pembentukan self-efficacy demi mencapai kinerja optimal mereka. Dengan adanya umpan balik kinerja, pemberian tugas-tugas yang menantang, dukungan atasan terhadap pembinaan karir, diharapkan karyawan juga dapat mengetahui kesempatan untuk mengembangkan keahlian mereka untuk bertumbuh bersama organisasi (Bacal, 2002; Greenhaus, et al., 1990). Dengan demikian, dalam diri karyawan akan terbentuk self-efficacy atau kepercayaan diri atas kemampuan mereka dan meyakini bahwa kemampuan mereka sangat dihargai dan dibutuhkan oleh organisasi.

Untuk penelitian selanjutnya, penelitian dapat dilakukan dengan menggunakan 3 (tiga) dimensi dari kinerja individual karyawan, yakni kinerja tugas, kinerja kontekstual, dan periaku kontraproduktif. Untuk menambah literature pengembangan dalam konteks psikologi industri dan organisasi, diharapkan peneliti selanjutnya dapat terus mengembangkan alat ukur kinerja individual ini agar dapat diadaptasi di Indonesia secara reliabel dan valid dengan menyesuaikan kepada budaya kerja karyawan di Indonesia. Karena pada dasarnya alat ukur kinerja ini memiliki tingkat reliabilitas yang tinggi, dan merupakan alat ukur kinerja multi-dimensional yang menilai perilaku relevan dalam konteks pekerjaan, dan pengujian cross-cultural adaptation baru dilakukan untuk negara bagian Eropa dan Amerika. 


\section{Ucapan Terima Kasih (acknowledgement)}

Terima kasih kami ucapkan kepada PT X yang memberikan dukungan dalam penyelesaian penelitian ini. Terima kasih juga untuk seluruh partisipan dan pihak-pihak utama yang telah berkontribusi dalam penelitian ini.

\section{REFERENSI}

Azman, I., Sieng, L. L. C., Ajis, M. N. E., Dollah, N. F., \& Boerhannoeddin, A. (2009). Relationship between supervisor's role and job performance in the workplace training program. Analele Stiintifice ale Universitatii" Alexandru Ioan Cuza" din Iasi-Stiinte Economice, 56, 237-251.

Bacal, R. (2002). Performance management: Memberdayakan karyawan meningkatkan umpan balik mengukur kinerja ( ed.). (S. Dharma, \& Y. Irawan, Penerj.) Jakarta: PT Gramedia Pustaka Utama.

Ballatine, K., \& Nunns, C. G. (1998). The moderating effect of supervisory support on the self-efficacy work performance relationship. S.Afr. J. Psychol, 28(3), 164-172.

Bandura, A. (1986). Social foundations of thought and action: A social cognitive theory. Englewood Cliffs, NJ: Prentice Hall.

Bandura, A. (1989). Human agency in social cognitive theory. American psychologist, 44(9), 1175.

Bandura, A., \& Locke, E. A. (2003). Negative self-efficacy and goal effects revisited. Journal of applied psychology, 88(1), 87.

Baron, R. M., \& Kenny, D. A. (1986). The moderator-mediator variable distinction in social psychological research: Conceptual, strategic, and statistical considerations. Journal of personality and social psychology, 51(6), 1173.

Biro Kerja sama, Hukum, dan Humas LIPI. (2017, April 28). SDM dan Iptek Pilar Penting Peningkatan Daya Saing Bangsa. Diambil kembali dari Lembaga Ilmu Pengetahuan Indonesia (LIPI): http://lipi.go.id/berita/sdm-dan-iptek-pilar-penting-peningkatan-daya-saing-bangsa/18094

Byrne, Z. S., Dik, B. J., \& Chiaburu, D. S. (2008). Alternatives to traditional mentoring in fostering career success. Journal of Vocational Behavior, 72(3), 429-442.

Chen, G., Gully, S. M., \& Eden, D. (2001). Validation of a new general self-efficacy scale. Organizational research methods, 4(1), 62-83.

Cherian, J., \& Jacob, J. (2013). Impact of self efficacy on motivation and performance of employees. International Journal of Business and Management, 8(14), 80 - 88.

Greenhaus, J. H., Parasuraman, S., \& Wormley, W. M. (1990). Effect of race on organizational experience, job perfomance evaluations, and career outcomes. Academy of Management Journal, 33(1), 64-86.

Kenny, D. A., Mohr, C. D., \& Levesque, M. J. (2001). A social relations variance partitioning of dyadic behavior. Psychological Bulletin, 127, 128-141.

Koopmans, L., Bernaards, C. M., Hildebrandt, V. H., van der beek, A. J., \& de Vet, H. C. (2014). Construct validity of the individual work performance questionnaire. American College of Occupational and Environmental Medicine, 56, 331-337.

Koopmans, L., Bernaards, C. M., Hildenbrandt, V. H., Schaufeli, W. B., de Vet, H. C., \& van der Beek, A. J. (2011). Conceptual frameworks of individual work performance a systematic review. JOEM, 53(8), 856 - 866.

Litzky, B., \& Greenhaus, J. (2007). The relationship between gender and aspirations to senior management. Career Development International, 12(7), 637-659.

Media Indonesia Online. (2017, Juli 11). Kondisi Pendudukan Indonesia Tahun 2045. Diambil kembali dari Media Indonesia E-Paper Media: http://mediaindonesia.com/read/detail/112438-kondisipendudukan-indonesia-tahun-2045.

Myers, K. K., \& Sadaghiani, K. (2010). Millennials in the workplace: a communication perspective on millennials' organizational relationships and performance. J Bus Psychol, 225-238.

Ng, E. S., Schweitzer, L., \& Lyons, S. T. (2010). New generation, great expectation: A field study of the millenial generation. J Bus Psychol, 25, 281-291. doi:10.1007/s10869-010-9159-4 
Noe, R. A., Hollenbeck, J. R., Gerhart, B., \& Wright, P. M. (2010). Manajemen sumber daya manusia: mencapai keunggulan bersaing (6 ed.). (D. Wijaya, Penerj.) Jakarta: Salemba Empat.

Preacher, K. J \& Hayes, A. F., 2004. SPSS and SAS Procedures for Estimating Indirect Effects in Simple Mediation Models. Behavior Research Methods, Instruments, \& Computers, 36 (4), 717-731. Psychonomic Society, Inc.

Rahadi, D. R. (2010). Manajemen kinerja sumber daya manusia (I ed.). Malang: Tunggal Mandiri Publishing.

Reeves, T. C., \& Oh, E. (2008). Generational differences. Dalam P. Harris, J. M. Spector, M. D. Merrill, J. v. Merriënboer, \& M. P. Driscoll (Penyunt.), Handbook Of Research On Educational Communications And Technology (Third Ed. (AECT Series) ed., hal. 295-303). Texas: Routledge.

Rigotti, T., Schyns, B., \& Mohr, G. (2008). A short version of the occupational self-efficacy scale: Structural and construct validity across five countries. Journal of Career Assessment, 16(2), 238255. doi:10.1177/1069072707305763

Schwarzer, R. Jerusalem. M.(1995). Generalized Self-Efficacy Scale. J. WEINMAN.

Schwab, K. (2017). The global competitiveness report. Switzerland: World Economic Forum. Diambil kembali dari www.weforum.org.

Shanock, L. R., \& Eisenberger, R. (2006). When supervisors feel supported: relationships with subordinates'perceived supervisor support, perceived organizational support,and performance. Journal of Applied Psychology, 91(3), 689-695.

Sonnentag, S., Volmer, J., \& Spychala, A. (2008). Job performance. The Sage handbook of organizational behavior, 1, 427-447.

Stajkovic, A. D., \& Luthans, F. (1998). Self-efficacy and work related performance: A meta analysis. Psychological Bulletin, 124(2), 240-261.

Walumbwa, F. O., Avolio, B. J., \& Zhu, W. (2008). How transformational leadership weaves its influence on individual job performance: The role of identification and efficacy beliefs. Personnel Psychology, 61, 793-825. 